\title{
SUSTAINABLE URBAN TOURISM DEVELOPMENT AND QUALITY OF LIFE: A CASE OF KAMPUNG BHARU, KUALA LUMPUR
}

\author{
MOHD HAFIZ HANAFIAH'ㄹ, AHMAD FITRI AMIR ${ }^{1}$, NURUL NAZIRAH SHAMSUL KAMAL ${ }^{2}$, \\ NUR NABIHAH SAHARUDDIN ${ }^{3}$ \\ ${ }^{1}$ Faculty of Hotel and Tourism Management, Universiti Teknologi MARA, Malaysia \\ ${ }^{2}$ Bank Islam Hub, Bandar Wawasan, Kuala Lumpur \\ ${ }^{3}$ Accenture Technology Solutions Sdn Bhd, Kuala Lumpur
}

\begin{abstract}
Mailing address: Mohd Hafiz Hanafiah, Universiti Teknologi MARA, Faculty of Hotel and Tourism Management, 42300 Puncak Alam, Malaysia, e-mail: hafizhanafiah@uitm.edu.my
\end{abstract}

\begin{abstract}
Introduction. With the transformation of Kuala Lumpur as a mega city and the boom of Malaysian urban tourism, understanding the interaction between tourism and local community livability is important for sustainable urban tourism development. Material and methods. Founded in 1899, Kampung Bharu is a famous traditional Malay village facing conflicting urban development and local community livability issues. Thus, to understand the local community perception of urban tourism development and its effect on their quality of life, this study investigates the effect of sustainable tourism development on the local Kampung Bharu community's quality of life. This study collected 364 valid responses from the local community through a self-administered survey. Results. The study confirms that economic and environmental impacts of urban tourism development deteriorate the local community's quality of life. However, the socio-cultural impacts of urban tourism development positively and significantly enhance the quality of life of the local community in Kampung Bharu. Conclusions. The study highlighted the importance of the local community's perceptions, community attachment, and perceived quality of life to destination managers responsible for planning and developing future tourism projects. Several limitations and recommendations for future research are presented.
\end{abstract}

Key words: urban tourism, sustainable tourism development, tourism impact, quality of life, Kampung Bharu

\section{Introduction}

The tourism industry is considered the key element in urban development policies as it integrates the economy and social life components within its developmental framework $[1,2]$. The emergence of the urban city features prospers the integration of the tourism industry within the urban dynamics, socalled urban tourism [3, 4]. Most metropolitan cities are major tourist destinations as they possessed various tourism-related facilities and better up-to-date infrastructures. Urban tourism attributes include the availability of natural and human-made attractions and tourist-related supporting facility services [5, 6]. However, the growth of urban tourism has increased the pressure on the environmental, social, and economic resources [7]. As the attributes of urban tourism vary and are complex, destination planners must understand better residents' perceptions of the impact of urban tourism development. The demand for urban tourism is likely to continue in the future $[5,8]$. However, without correct planning, urban tourism may offer unfavourable consequences to the local community.

Since more and more cities presented themselves as the loveliest, glittering, or touching destination to the visitors, urban tourism has become a mainstream tourism research topic [5] with various positive and negative impacts. According to research on community perceptions of tourist development, the effects of tourism development can be seen both positively and adversely [7, 12]. Notably, the impacts of urban tourism development vary both positively and negatively depending on economic, social, cultural and environmental aspects. Among the positive impacts of the development are increased residents' quality of life, improved infrastructures and public amenities, new job opportunities, established local business prospects and preserved local cultures [9]. Nevertheless, researchers also claimed that if not controlled, tourism development may contribute to severe environmental issues and generate social and cultural problems [10]. Strategies were developed to minimise the negative impact, which concurrently would maximise the positive impact. Consequently, sustainable tourism development has been suggested to maximise the positive and minimise the adverse effects of tourism activities [1, 11]. However, the effects can only be felt if the tourism business cycle is promising; thus, researchers claimed that most of the community that receive high tourist arrivals would support tourism development $[16,17]$. If the community benefited from the tourism activities, they will be encouraged to support further tourism developments [13]. However, they might develop the opposite effect if they did not receive the favourable impact from such development $[14,15]$. Hence, understanding the interaction between tourism and local community livability is important for urban tourism sustainability.

Based on the study aims elaboration, this paper introduces the research settings, reports the relevant literature review and discusses the study hypothesis development. This is followed by describing the research methodology, including target population, sampling technique and survey instruments. Subsequently, the structural equation modelling assessment was described and reported. Finally, the paper concludes with the findings' elaboration, limitations and conclusion.

\section{Research Setting: Kampung Bharu, Kuala Lumpur}

There are various popular urban tourism cities in the world, and Kuala Lumpur is one of them. Kampung Bharu is one of the 'must-visit' places for tourists who come to Kuala Lumpur because it offers a unique gastronomy experience and cultural 
heritage [18]. Kampung Bharu was founded in 1899 and had a strong sense of history tied to several factors but is well known for its Malay wooden houses [19]. Kampung Bharu is one of the villages developed in the inner Kuala Lumpur city. Currently, it has sustained its place as the image and identity of cultural tourism [20]. In order to promote Kampung Bharu as a tourist destination, the Ministry of Tourism has promoted it through the travel package known as "Jalan-Jalan@Kampung Bharu", which is offered and guided by the Kuala Lumpur Tourism Bureau [21].

In recent years, the development of tourism in Kuala Lumpur has slowly eroded the heritage value of Kampung Bharu as the tourism activity heavily focused on shopping and leisure activities. According to Hanipah and Foo [21], Kuala Lumpur development has slowly deteriorated the charm of Kampung Bharu as a unique cultural and heritage attraction. Moreover, the influx of foreigners and the increase in property value in the city have negatively affected Kampung Bharu's image as an authentic Malay village, besides the rise of social problems in the area [22]. Foreigners were reported monopolising the businesses in Kampung Bharu, and the situation has caused uneasiness among the local community there [23]. This disorganised condition had made the local community feel uncomfortable and they decided to move out from the area over time.

With the transformation of Kuala Lumpur as a mega-urban tourism destination, understanding the interaction between tourism and Kampung Bharu local community livability is important for sustainable urban tourism development. Besides, as Ujang et al. [20] mentioned, Kampung Bharu has been negatively affected by rapid tourism development in Kuala Lumpur; thus, it needs improvements from the perspective of facilities and physical development and image building. In addition, previous tourism scholars have neglected empirical studies on urban tourism, specifically in Kampung Bharu. As the study investigates local communities' perception of sustainable urban tourism development at Kampung Bharu, Kuala Lumpur, the findings from this study could highlight the importance of preserving local heritage and the significance of addressing the local community's view in tourism development without ignoring the benefit of tourism activities to the local community.

\section{Literature review}

\section{Urban Tourism}

Defining urban tourism has always been controversial. European Commission [26] described urban tourism as "a group of tourist attractions or activities located in towns and cities and offered to visitors from elsewhere" (p. 21). The United Nations World Tourism Organization defined urban tourism as "a tourist activity in urban space" that provides cultural, architectural, technological, social and natural experiences and products for leisure and business activities [27]. On the other hand, Li et al. [28] propose that the core of urban tourism relies on leisure within cultural venues and various consumer places provided within the urban space.

The urban tourism research mainly focused on the late 1980s and received disproportionate attention among tourism scholars [24, 25]. Notably, opportunities and challenges for urban tourism have been noted in the literature about various tourism cities globally. First, using Addis Ababa as the research setting, Kidane-Mariam [29] reported positive impacts from urban tourism activities such as the rich and diversified cultural and natural heritage, economic growth, and expansion of infrastructure development. However, poor sanitation, hotels and restaurants mismanagement, and lack of regulation of tourist-related infrastructures and services adversely affect urban tourism development.

On the other hand, Rajasthan, India, is popular with its culture, tradition, cuisine, costumes and arts. However, it faces challenges of underdeveloped transport and communication networks [30]. In 2010, Berlin's city faced heated public debate on the effects of tourism in generating pub crawls, noise complaints, and the conversion of apartments into holiday flats, which are primarily catalysed by increased tourism activities [31]. In addition, tourism conflicts with the local community create anti-tourism urban movements that explain Barcelona's tourismophobia phenomenon [32, 33]. Meanwhile, the destructive nature of overtourism in Krakow (Polish tourist city) causes rapid anti-tourist protests and acute impact on the local community [34]. It seems that conflicts that arise among the tourism cities are a result of bad destination governance and unsustainable tourism development $[35,34]$

Sustainable Tourism Development and Quality of Life

The nature of tourism development is twofold: its capacity to deliver social and economic benefits to the community while deteriorating its environmental and physical resources [36]. Hence, the role of resident support in tourism development is widely recognised [16]. Local residents have constantly been regarded as one of the most critical stakeholders in the sustainability of tourism destinations [36]. Since then, many researchers have emphasised that tourism development has contributed to the local community's quality of life by creating job opportunities, preservation of local culture and pride, and proliferating the local community's economy [37]. On the other hand, adverse economic effects are also possible since tourism activities might increase property prices, the local community's living costs, and taxes [12]. Tourism scholars proposed the importance of weight in the local residents' behaviour towards sustainable tourism development $[8,36]$. Subsequently, various researchers reported that residents' perceptions of the impact of tourist development on their communities would influence their willingness to support future tourism development.

Tourism growth, planning, successful operation, and sustainability require continuous assistance of the local community. Hence, the research on residents' perception of tourist destinations is one of the hottest topics studied by scholars. Various studies have focused on the impacts of tourism and community perception on the impacts of tourism development. The perception of residents is one of the key factors determining a tourist destination's success [38]. Based on Social Exchange Theory, the local community will respond favourably if tourism development produces positive impact on them rather than a negative impact [16]. Many scholars define local communities' perception based on how they perceive the tourism activities affecting them directly or indirectly related to them [12, 36, 37]. If the perception of tourism is positive, it may lead to greater support and impactful tourism activities and vice versa. Thus, most studies have proven that the community that perceived a personal benefit or greater economic gain tends to perceive tourism development positively. Also, the local community will respond more to tourism development if their quality of life is increasing [36]. To achieve an optimal quality of life, stakeholders from all sectors, namely the local community, tourists, government, NGO and industrial players, must work as a team to achieve sustainable tourism goals [40].

Cottrell et al. [41] claimed that the local community's perception is one of the important elements in encouraging future 


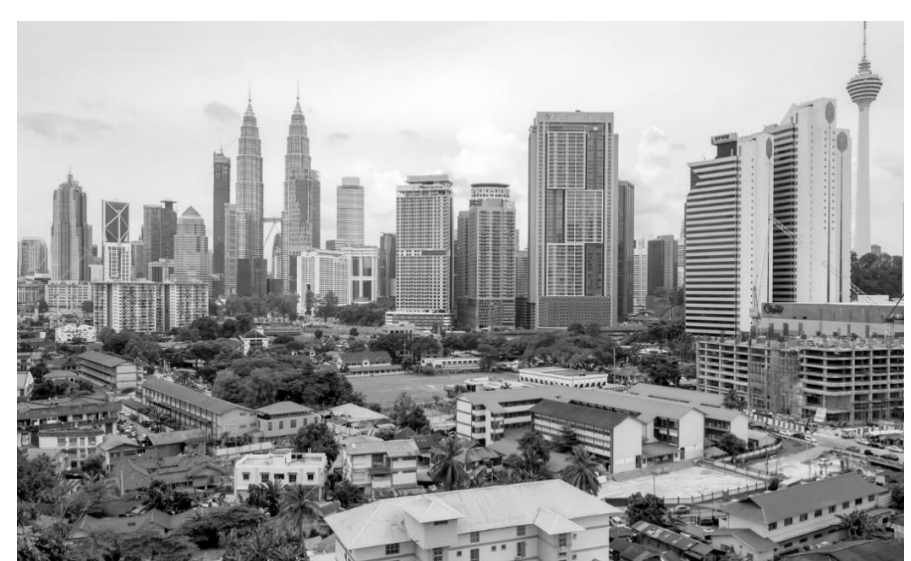

Source: Google Photo

Figure 1. A view of Kampung Baru and KLCC

participation in tourism development due to a sense of closeness with the situation in life. The local community's perception is based on their situation in life, which can also determine how they perceive tourism development in improving their quality of life. Individual and family life satisfaction, enjoyment with the neighbour, community, and personal status are quality of life elements favoured by the community. Various researchers have investigated aspects of residents' quality of life in the urban tourist destination and examine the relationship between tourism development and quality of life $[36,37]$. The tourism development impact is the contributors that will directly affect the community in terms of their lifestyles, community values, and quality of life. Previous research has found a link between community views regarding the current and future tourism development and sustainable urban tourism development [42]. However, it may lead to negative consequences if it was poorly planned. Therefore, it is crucial to create and promote a positive perception among the community as it affects their quality of life and consequently their support towards future tourism development [16].

Various methods have been used to test the views of local communities on tourism development impact [39]. Past studies claim that tourism development impact on the local community can be assessed based on three dimensions: economy, environment, and socio-cultural [36]. The economic impact includes job opportunities and additional income to the locals [8]. Cultural recognition and cultural interchange between the tourist and the host are socio-cultural implications [43]. Similarly, various studies have examined how these factors may affect or influence future tourist development and the quality of life in the local community $[36,44]$. According to them, economic, environmental, social, and cultural influences on local communities are vital pillars of sustainable tourism development. Most of these studies have proven that the community that perceived a personal benefit or greater economic, environmental, and socio-cultural gain from sustainable tourism development tends to have a better quality of life and positively supports future tourism development.

\section{Economic Impact of Tourism Development}

Economic benefits are the most critical elements local communities seek from tourism development. Many studies revealed positive and negative economic impacts of tourism on local communities [37, 45]. From the economic perspective, tourism activities can create job opportunities for local people. Tourism can bring money into tourists' spending on

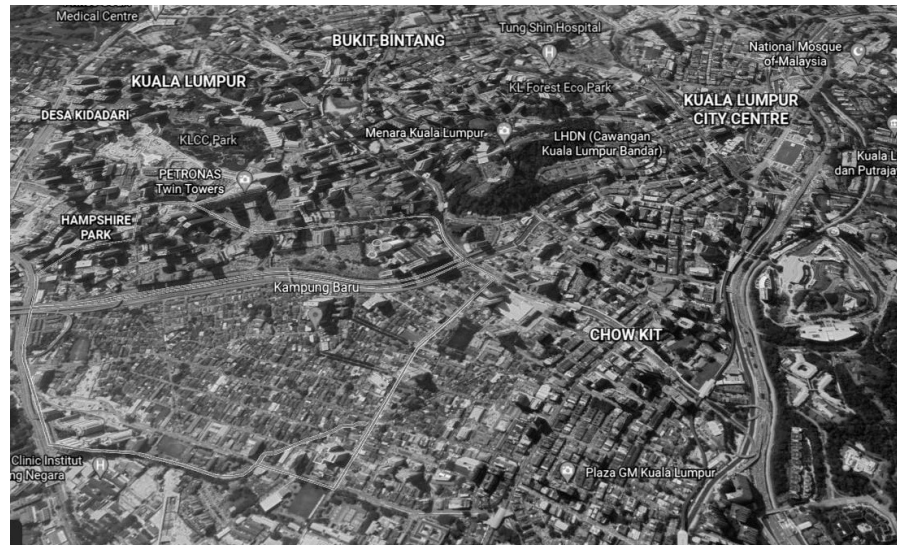

Source: Google Earth

Figure 2. Kampung Baru Map

tour packages, accommodation, food, entertainment, and recreation. Tourism activities can provide a source of income for the locals and stimulate positive economic development for the communities with few other possible sources of revenue [36]. The improvement of economic structure can cause to stimulate the local economy and raise the standard of living of the local communities [14, 36].

Urban tourism development was found to improve public utilities, transport infrastructure, and income for the local communities. Similarly, Hanafiah et al. [16] agree that tourism activities in a tourist destination positively impact economic well-being. Despite having sound effects like boosting local economies and providing new job opportunities and revenue, uncontrolled urban tourism expansion can have a negative impact $[42,43]$. Notably, there are also economic costs associated with the growth of tourism, such as economic leakage, disparities in financial distribution, high living costs, increase in prices for goods and services, and increase in property and land prices [43]. However, it is believed that only a tiny proportion of the local community derive these benefits [17, 45]. Thus, this study proposed that the local community's quality of life will be improved by the economic benefits of urban tourism development and activities. Thus, this study proposed:

\section{$\mathrm{H}_{1}$ : Local communities' perceived economic impact from tourism development positively affects their quality of life.}

\section{Environmental Impact of Tourism Development}

The environmental impact of tourism development is difficult to describe as it is complex and environment-specific. The positive effects of tourism development towards environmental sustainability are mainly derived from its benefits in the preservation of natural resources and improvement in the ecological environment of the community in many ways. However, the tourism-environmental aspect has also had a substantial negative impact, especially in urban areas [5]. Some of the negative effects of tourism activities include noise and traffic congestion, as mentioned by a few researchers [3]. Besides, other researchers also highlighted how tourism activities could negatively impact the environment, producing noise, litter, property destruction, and other types of pollutions [45]. Besides, the increasing number of tourists has led to an increase in $\mathrm{CO}_{2}$ emission and contributed to environmental pollution [43]. Based on the literature, several studies examined the environmental attitudes and values of the local community and their subsequent effects on the local community's views about future tourism develop- 
ment [44]. Their study found that the local community was concerned about the positive impacts on the environment and the negative impacts. Hence, this study proposed that the local community's quality of life will be improved by the positive environmental impact of urban tourism development and activities. Therefore, this study proposed:

$\mathrm{H}_{2}$ : Local communities' perceived environmental impact from tourism development positively affects their quality of life.

\section{Socio-Cultural Impact of Tourism Development}

Apart from the environmental impact, the socio-cultural impact was one of the highest weights in the resident dimension that needs to be seriously acknowledged in the future. The socio-cultural impact can be positive and negative, changing the individual's value system, behaviour pattern, and lifestyle [43]. Tourism development affects the socio-cultural character of the local community, such as habits, daily routines, social lives, beliefs, and values. However, it has the potential to improve the community's quality of life. According to Gupta and Dutta [45], tourist development has a detrimental influence on the quality of life due to an increase in visitors, which causes overcrowding, traffic congestion, increased crime, and litter. These would lower the local community's quality of life, and as a result, citizens may withdraw their support for tourism development [43]. According to the current study, there is a link between negative social repercussions and community perceptions of tourism development [14]. Hence, this study proposed that the local community's quality of life will be improved by the favourable socio-cultural impact of urban tourism development and activities. Thus, this study proposed:

$\mathrm{H}_{3}$ : Local communities' perceived socio-cultural impact from tourism development positively affect their quality of life.

\section{Research methodology}

The relationship between sustainable tourism impacts and quality of life is investigated in this paper, with Kampung Bharu as the urban tourist setting. Local community perceptions of tourism development impact and quality of life are the critical research constructs. The research economic, environmental, socio-cultural, and quality of life impacts were measured using instruments adapted from Peters et al. [8] and Hanafiah et al. [16]. This 13-item scale consists of four dimensions affixed with a five-point Likert type scale. The study unit of analysis is the Kampung Bharu local community that resides within the gazetted tourism area. Purposive sampling was used to select the study respondents.

The surveys were conducted from March to May 2020. A total of 364 responses were usable for the data analysis. As shown in Table 1, $57.7 \%$ of the respondents were male, and $72.2 \%$ of the respondents resided in Kampung Bharu for more than five years. In terms of occupation, $50 \%$ of the respondents were working professionals, while $29.7 \%$ were government servants, with $73 \%$ holding diplomas. Most respondents claimed that their annual income is less than MYR50k and were aged between 30 and 39 years old.

\section{Data analysis and findings}

Two stages of procedures were undertaken to execute the Partial Least Squares Structural Equation Model (PLS-SEM) analysis via the SmartPLS 3.11 software. The first stage is the in-
Table 1. Demographic profile

\begin{tabular}{|c|c|c|}
\hline & Frequency & Percent \\
\hline \multicolumn{3}{|l|}{ Age } \\
\hline 18 to 29 years & 51 & 14.6 \\
\hline 30 to 39 years & 158 & 43.4 \\
\hline 40 to 59 years & 110 & 30.2 \\
\hline 60 years and above & 45 & 11.8 \\
\hline \multicolumn{3}{|l|}{ Gender } \\
\hline Male & 210 & 57.7 \\
\hline Female & 154 & 42.3 \\
\hline \multicolumn{3}{|c|}{ Length of residing at Kampung Bharu } \\
\hline Less than five years & 101 & 27.6 \\
\hline Five to ten years & 169 & 46.4 \\
\hline More than ten years & 94 & 25.8 \\
\hline \multicolumn{3}{|l|}{ Marital Status } \\
\hline Single & 114 & 31.3 \\
\hline Married & 238 & 65.4 \\
\hline Widowed/Divorced & 12 & 3.3 \\
\hline \multicolumn{3}{|l|}{ Education Level } \\
\hline High School and lower & 60 & 16.5 \\
\hline Diploma & 268 & 73.6 \\
\hline Undergraduate degree & 36 & 9.9 \\
\hline \multicolumn{3}{|l|}{ Occupation } \\
\hline Government servant & 108 & 29.7 \\
\hline Self-employed & 68 & 18.7 \\
\hline Professional (private sector) & 182 & 50.0 \\
\hline Unemployed & 6 & 1.6 \\
\hline \multicolumn{3}{|l|}{ Household Income } \\
\hline Less than RM50,000 annually & 277 & 76.1 \\
\hline Less than RM100,000 annually & 66 & 18.1 \\
\hline More than RM100,000 annually & 21 & 5.8 \\
\hline
\end{tabular}

$\mathrm{n}=364$.

ner-model or measurement model evaluation, known as confirmatory factor analysis (CFA), which measures items through psychometric reliability and validity tests. The measurement model specifies the relationships between unobserved or latent variables. Next is the structural model that focuses on the relationship between the underlying exogenous and endogenous constructs.

\section{Measurement Model}

In the process of examining the reflective measurement models, the four parameters need to be taken into account to meet statistical requirements: (i) internal consistency reliability, (ii) indicator reliability, (iii) convergent validity and (iv) discriminant validity [46, 47]. Table 2 below reports the outer loading, indicator reliability, composite reliability, AVE scores and the Cronbach Alpha value for the reflective measurement model.

Table 2 reports that all item factor loadings are higher than the minimum threshold $(>.70)$, ranging from 0.707 to 0.89 , verifying the reliability of the research instruments [46] 
Table 2. Measurement Model

\begin{tabular}{|c|c|c|c|c|c|c|}
\hline Latent Variable & $\begin{array}{c}\text { Indi- } \\
\text { cators }\end{array}$ & $\begin{array}{c}\text { Load- } \\
\text { ings }\end{array}$ & $\begin{array}{c}\text { Com- } \\
\text { posite } \\
\text { Relia- } \\
\text { bility }\end{array}$ & AVE & $\begin{array}{c}\text { Cron- } \\
\text { bach } \\
\text { Alpha }\end{array}$ & Mean \\
\hline Economic impact & EC1 & 0.707 & 0.823 & 0.619 & 0.791 & 4.80 \\
\hline & EC2 & 0.790 & & & & 4.63 \\
\hline & EC3 & 0.767 & & & & 4.51 \\
\hline & EC4 & 0.720 & & & & 4.20 \\
\hline Environmental impact & EV1 & 0.746 & 0.813 & 0.589 & 0.751 & 4.87 \\
\hline & EV2 & 0.741 & & & & 4.73 \\
\hline & EV3 & 0.786 & & & & 3.70 \\
\hline & EV4 & 0.723 & & & & 4.04 \\
\hline Socio-cultural impact & SC1 & 0.841 & 0.822 & 0.597 & 0.754 & 4.59 \\
\hline & SC2 & 0.743 & & & & 4.76 \\
\hline & SC3 & 0.781 & & & & 4.41 \\
\hline & SC4 & 0.722 & & & & 4.87 \\
\hline & QOL1 & 0.893 & 0.908 & 0.649 & 0.852 & 3.92 \\
\hline Quality of Life & QOL2 & 0.865 & & & & 3.81 \\
\hline & QOL3 & 0.881 & & & & 3.67 \\
\hline & QOL4 & 0.857 & & & & 3.64 \\
\hline & QOL5 & 0.798 & & & & 3.70 \\
\hline
\end{tabular}

$\mathrm{n}=364$.

Meanwhile, the AVE values of all constructs were above the required minimum level of 0.50 , indicating high levels of convergent validity and exhibited high reliability. Next, the heterotrait-monotrait ratio of correlations (HTMT) is a new method for assessing discriminant validity in PLS-SEM [48]. The HTMT values $(<0.85)$ indicated no discriminant validity problems. Overall, the measurement mode supports the discriminant validity between the constructs.

\section{Structural Model}

Using the SmartPLS algorithm output, the relationships between independent and dependent variables were examined through the regression coefficient $(\beta)$ value. The path coefficients revealed that economic impact from tourism development significantly and negatively affected the local community's quality of life $\left(\beta=-0.422^{* * *}\right)$. The result also confirms that environmental impact from tourism development negatively influences the local community's quality of life $\left(\beta=-0.125^{* * *}\right)$. Lastly, the path coefficients revealed that socio-cultural impact

Table 3. HTMT results

\begin{tabular}{|c|c|c|c|c|}
\hline & $\begin{array}{c}\text { Economic } \\
\text { impact }\end{array}$ & $\begin{array}{c}\text { Environmental } \\
\text { impact }\end{array}$ & $\begin{array}{c}\text { Socio-cultural } \\
\text { impact }\end{array}$ & $\begin{array}{c}\text { Quality of } \\
\text { Life }\end{array}$ \\
\hline $\begin{array}{c}\text { Economic } \\
\text { impact }\end{array}$ & 1 & 1 & 1 & \\
\hline $\begin{array}{c}\text { Environmental } \\
\text { impact }\end{array}$ & 0.718 & 0.829 & 1 & \\
\hline $\begin{array}{c}\text { Socio-cultural } \\
\text { impact }\end{array}$ & 0.833 & 0.834 & 0.815 & 1 \\
\hline $\begin{array}{c}\text { Quality of } \\
\text { Life }\end{array}$ & 0.823 & & & \\
\hline
\end{tabular}

from tourism development significantly and positively affects their quality of life $\left(\beta=0.142^{* * *}\right)$.

Based on the effect size, the path coefficient for environmental impact has weak effects on quality of life. In contrast, the path coefficient for economic and socio-cultural impact has a moderate effect on the quality of life. Next, the coefficient of determination $\left(\mathrm{R}^{2}\right)$ of the relationship between the independent variables (economic, environmental, and socio-cultural impact) and the dependent variable (quality of life) is $43.7 \%$, with the substantial predictive power of $\mathrm{Q}^{2}=0.225$. This result confirms that the structural model is within a good fit. The following section discusses the above results in detail.

Table 4. Path coefficients, observed T-statistics, and significance levels.

\begin{tabular}{|c|c|c|c|}
\hline Hypotheses & Beta $(\beta)$ & T Stat & Effect Size \\
\hline $\begin{array}{c}\mathrm{H}_{1}: \text { Economic Impact } \\
\rightarrow \text { Quality of Life }\end{array}$ & $-0.422^{* * *}$ & 6.242 & $\begin{array}{c}0.132-\text { Moderate effect } \\
\text { size }\end{array}$ \\
\hline $\begin{array}{c}\mathrm{H}_{2}: \text { Environmental Impact } \\
\rightarrow \text { Quality of Life }\end{array}$ & $-0.125^{\star * *}$ & 2.365 & $0.059-$ Small effect size \\
\hline $\begin{array}{c}\mathrm{H}_{3}: \text { Socio-cultural impact } \\
\rightarrow \text { Quality of Life }\end{array}$ & $0.142^{* *}$ & 2.788 & $\begin{array}{c}0.171-\text { Moderate effect } \\
\text { size }\end{array}$ \\
\hline
\end{tabular}

${ }^{* * *}-\mathrm{p}<0.01 ;{ }^{* *}-\mathrm{p}<0.05 ; \mathrm{R}^{2}-0.437 ; \mathrm{Q}^{2}-0.225$.

\section{Discussion}

The main goal of this study was to look into the economic, environmental, and socio-cultural effects of tourist development on the quality of life of the local people in Kampung Bharu. First, contrary to prior research, this study indicated that the economic impact of tourist development in Kampung Bharu does not improve the quality of life of the local people. This finding contradicts the findings of numerous studies (e.g. [36, 45]). According to the social exchange theory, most identified a favourable association between perceived economic impact and quality of life. According to Ujang et al. [20], the negative economic impact may have resulted from an increase in the price of goods and services and an increase in the price of food and land, including property taxes. Besides that, the environmental impact on the quality of life was relatively negative due to traffic congestion, noise and pollution. This result is in line with previous studies where the issues of pollution, littering, traffic congestion, and noise by tourism activities affect the hosting residents [43]. This result has also proved that tourism development in Kampung Bharu negatively affects the communities at large [49].

On the other hand, this study found that the quality of life of the local community was perceived as positive from the socio-cultural standpoint as it allows the preservation of local culture and gives a favourable impact on cultural identity. This result is consistent with other studies (e.g. [41, 43] that there was a positive relationship between perceived social impact and the quality of life. With tourism development, the government preserved Kampung Bharu's unique Malay houses representing the local Malay lifestyles' physical and social environment [21]. The functionality and availability of recreational amenities for locals have also improved due to tourism development. Tourism activities provide more possibilities to update facilities, parks, and roads, thus enhancing their quality of life [36, 40, 47]. This study highlighted the importance of the community attachments and perceived quality of life to destination managers responsible for planning and developing future urban tourism projects. 
The current condition of the Covid-19 pandemic threatens the stability of the country's tourism sector as it affects the ability of people to travel [50]. With the increasing number of people infected, almost all international borders are expected to fall potentially beyond 2021 as tourists tend to avoid unnecessary travel. Travelling regularly will be more difficult, as border closures may limit their movement. The movement control policy resulted in further uncertainty and challenges in the future of the tourism industry related to the complicated travelling procedures for international tourists and complex requirements for crossing the international border.

Even before the pandemic, most urban tourism destinations saw reducing numbers of travellers as most modern tourists opt to visit green tourism destinations - avoiding the congestion and polluted destination. Rural tourism, for example, ranks as the main competitor of urban tourism. This situation is expected to become more complicated with the Covid-19 pandemic virus that spreads more easily. There will likely be a higher pattern of tourists engaging in rural tourism activities to avoid congested areas, affecting the demand for urban tourism and indirectly affecting tourism businesses and communities. With this in mind, the sustainability of urban tourism is in jeopardy. More importantly, in view of the post-Covid-19 era, a clear direction must be underlined and highlighted to build confidence and greater acceptance of urban tourism. Tourism policymakers should scrutinise the drawbacks and strengths of their urban tourism policies and marketing strategies in generating domestic and international market demand.

\section{Study limitation}

This study focuses on a specific urban tourism community which implies obvious limitations. Hence, a broader and more in-depth analysis could be conducted on other urban communities within the Kuala Lumpur city areas and of different levels of socioeconomic profile to understand the diversity of their perception and impact on quality of life. This would offer study generalisation and capture a more holistic understanding of the urban tourism development impact. Besides, comparative analysis in different cities would provide a more comprehensive understanding and patterns. Another limitation of this research is that it mainly focuses on Kuala Lumpur and therefore provides a partial understanding of the urban tourism activities in Malaysia. A comparative analysis between other popular cities in Malaysia such as Penang, Malacca and Johore Bharu could offer a lot of rich data and profiling.

Meanwhile, with the current Covid-19 pandemic situation, it is difficult to guarantee previous study findings legitimacy. The current condition of the Covid-19 pandemic threatens the economics of tourism activities. As over-tourism is not a problem, the local community's perception would differ as they realised the direct impact of under tourism. The movement control policy resulted in further uncertainty and challenges in the tourism industry's future and primarily affected tourism businesses. Hence, the study findings are limited to urban tourism sustainability and how Covid-19 would change the future demand for urban tourism activities.

\section{Conclusion}

The challenges of understanding sustainable tourism in cities are significant. Tourism is a complex and adaptive system. Previous research demonstrated that tourism impacts are varied and determine community's quality of life in many ways. This is never more evident than in urban tourism. Consequently, this study uncovered essential elements that affect the particular quality of life conditions within the urban tourism realm. This study examined the interplay of sustainable urban tourism development impact on community's quality of life. Both factors are significant predictors of their support towards future tourism development. Among the critical implications of this explanatory work is the importance of understanding factors that influence community perception towards the impacts of sustainable tourism activities. Sustainability implications of city tourism have been and will continue to be a major research area. Therefore, there is a need to recognise the critical roles of tourism's economic, cultural, social, and environmental impact.

In addition, tourism development should focus on the community's emotional, health and safety well-being domains. Specifically, over-tourism has become a significant problem in most urban destinations. The increasing number of inbound tourists dictates further research on the carrying capacity of urban tourism destinations. Consequently, many local communities harboured images of income disparity, instability, poor infrastructure and low quality of public facilities within urban tourism destinations. Hence, a practical foundation for examining community's quality of life through tourism impact assessment should be utilised for future development. Notably, this study highlights how the community's perception regarding the impact of tourism would influence their quality of life and how much enhancement in quality of life leads to better life satisfaction and directly affects their support towards tourism development. Nonetheless, these uncertain phenomena demand future researchers to build and regenerate what we learn from the past and forecast for the future sustainable development of urban tourism, aligned with the 2030 SDGs.

A fully functioning tourism system should understand and identify both tangible and intangible benefits and costs of tourism to its nearest stakeholders. Tourism scholars pointed out that the importance of gaining local communities' support for tourism development is a vital component in building a sustainable tourism industry. Thus, there is a need to understand better urban or city tourism and its impact on the host community. It is not known and well-worth exploring to what extent the host community support will decrease, leaving tourism businesses with, on the one hand, struggling to meet the business ends and, on the other hand, defunct the city's identity without the sense of community support.

\section{Acknowledgement}

This research is supported by Universiti Teknologi MARA (UiTM) Malaysia and Malaysia Institute of Transport (MITRANS) under the Mitrans grant: 600-RMC/MITRANS_IRES 5/3(019/2020).

\section{References}

1. Day J. (2020). Sustainable tourism in cities. In A.M. Morrison, J.A. Coca-Stefaniak (eds), Routledge Handbook of Tourism Cities (pp. 52-64). Routledge. https://doi. org/10.4324/9780429244605-3.

2. Hanafiah M.H., Zulkifly M.I. (2019). Tourism destination competitiveness and tourism performance: A secondary data approach. Competitiveness Review 29(5), 592-621. DOI: 10.1108/CR-07-2018-0045.

3. Liu J., Nijkamp P., Huang X., Lin D. (2017). Urban livability and tourism development in China: Analysis of sustainable 
development by means of spatial panel data. Habitat International 68, 99-107. DOI: 10.1016/j.habitatint.2017.02.005.

4. Yudha P., Radyan D.O., Akbar F.A. (2019). Urban tourism based on social capital development model. Eurasia: Economics and Business 1(19), 37-42. DOI: 10.18551/econeurasia.2019-01.05.

5. Bellini N., Go F.M., Pasquinelli C. (2017). Urban tourism and city development: notes for an integrated policy agenda. In N. Bellini, C. Pasquinelli (eds), Tourism in the City (pp. 333-339). Springer. DOI: 10.1007/978-3-319-26877-4.

6. Nilsson J.H. (2020). Conceptualising and contextualising overtourism: the dynamics of accelerating urban tourism. International Journal of Tourism Cities 6(4), 657-671. DOI: 10.1108/IJTC-08-2019-0117.

7. Koens K., Postma A. (2016). Understanding and managing visitor pressure in urban tourism. A study into the nature and methods used to manage visitor pressure in six major european cities. Leeuwarden/Breda/Vlissingen: CELTH.

8. Peters M., Chan C.S., Legerer A. (2018). Local perception of impact-attitudes-actions towards tourism development in the Urlaubsregion Murtal in Austria. Sustainability 10(7), 2360. DOI: 10.3390/sul0072360.

9. García F.A., Vázquez A.B., Macías R.C. (2015). Resident's attitudes towards the impacts of tourism. Tourism Management Perspectives 13, 33-40. DOI: 10.1016/j.tmp.2014.11.002.

10. Khavarian-Garmsir A.R., Zare S.M. (2015). SOAR framework as a new model for the strategic planning of sustainable tourism. Tourism Planning \& Development 12(3), 321332. DOI: $10.1080 / 21568316.2014 .960595$.

11. Ivars-Baidal J.A., Vera-Rebollo J.F., Perles-Ribes J., Femenia-Serra F., Celdrán-Bernabeu M.A. (2021). Sustainable tourism indicators: what's new within the smart city/destination approach? Journal of Sustainable Tourism 1-24. DOI: 10.1080/09669582.2021.1876075.

12. Rasoolimanesh S.M., Ringle C.M., Jaafar M., Ramayah T. (2017). Urban vs. rural destinations: Residents' perceptions, community participation and support for tourism development. Tourism Management 60, 147-158. DOI: 10.1016/j.tourman.2016.11.019.

13. Uğur L. (2017). Mind the gap: Reconceptualising inclusive development in support of integrated urban planning and tourism development. In N. Bellini, C. Pasquinelli (eds), Tourism in the City (pp. 51-66). Springer. DOI: 10.1007/9783-319-26877-4_3.

14. Eslami S., Khalifah Z., Mardani A., Streimikiene D., Han H. (2019). Community attachment, tourism impacts, quality of life and residents' support for sustainable tourism development. Journal of Travel and Tourism Marketing 36(9), 1061-1079. DOI: 10.1080/10548408.2019.1689224.

15. Woo E., Kim H., Uysal M. (2015). Life satisfaction and support for tourism development. Annals of Tourism Research 50, 84-97. DOI: 10.1016/j.annals.2014.11.001.

16. Hanafiah M.H., Jamaluddin M.R., Zulkifly M.I. (2013). Local community attitude and support towards tourism development in Tioman Island, Malaysia. Procedia-Social and Behavioral Sciences 105, 792-800. DOI: 10.1016/j. sbspro.2013.11.082.

17. Su L., Huang S., Huang J. (2018). Effects of destination social responsibility and tourism impacts on residents' support for tourism and perceived quality of life. Journal of Hospitality and Tourism Research 42(7), 1039-1057. DOI: 10.1177/1096348016671395.

18. Bouchon F.A. (2014). Truly Asia and global city? Branding strategies and contested identities in Kuala Lumpur. Place
Branding and Public Diplomacy 10(1), 6-18. DOI: 10.1057/ pb.2013.21.

19. Fujita M.A. (2010). Forays into building identity: Kampung to kampong in the Kuala Lumpur Metropolitan Area. Journal of Architectural Education 63(2), 8-24. DOI: 10.1111/j.1531-314X.2010.01055.x.

20. Ujang N., Moulay A., Zakaria J. (2018). Visitors' attachment to historic tourism places in Kuala Lumpur City centre towards sustainable urban regeneration. Environment-Behaviour Proceedings Journal 3(9), 165. DOI: 10.21834/e-bpj. v3i9.1521.

21. Hanipah A.A., Foo C.K. (2020). Socioeconomic impact on Kampung Baru: Revisiting the policy for the New Malaysia. Jurnal Undang-undang dan Masyarakat 24, 17-24. DOI: 10.17576/juum-2019-24-03.

22. Akbar P.N.G., Edelenbos J. (2020). Social impacts of place-making in urban informal settlements: A case study of Indonesian Kampungs. Social Sciences 9(6), 104. DOI: 10.3390/socsci9060104.

23. Ujang N. (2020). Planning for a redevelopment of a traditional urban village of Kampong Baru, Kuala Lumpur: A challenge for a sustainable future. In N. Bellini, C. Pasquinelli (eds), Urban and Transit Planning (pp. 163-168). Springer. DOI: 10.1007/978-3-030-17308-1_15.

24. Al-Saad S.A., Ababneh A. (2017). Concept, opportunities and challenges of urban tourism in the Arab world: Case studies of Dubai, Cairo and Amman. Tourism: An International Interdisciplinary Journal 65(3), 361-375.

25. Grah B., Dimovski V., Peterlin J. (2020). Managing sustainable urban tourism development: The case of Ljubljana. Sustainability 12(3), 792.

26. European Commission (2000). Towards Quality Tourism: Integrated Quality Management (IQM) of Urban Tourist Destinations. Luxembourg: Office for Official Publications of the European Communities.

27. UNWTO (2020). UNWTO statement on the novel coronavirus outbreak. Retrieved 1 May 2020 from: https://unwto. org/ unwto-statement-on-the-novel-coronavirus-outbreak.

28. Li Z., Zhang X., Yang K., Singer R., Cui R. (2021). Urban and rural tourism under covid-19 in China: Research on the recovery measures and tourism development. Tourism Review 76(4), 122.

29. Kidane-Mariam T. (2015). Ethiopia: opportunities and challenges of tourism development in the Addis Ababa-upper Rift Valley corridor. Journal of Tourism and Hospitality 4(4), 167-181.

30. Dharmwani L., Laveena T. (2013). Tourism in Rajasthan: Challenges and opportunities. Indian Journal of Applied Research 3(11), 63-64.

31. Holm A. (2014). Berlin's gentrification mainstream. In B. Grell, M. Bernt, A. Holm (eds), The Berlin Reader (pp. 171188). Transcript-Verlag.

32. Alvarez-Sousa A. (2018). The problems of tourist sustainability in cultural cities: Socio-political perceptions and interests management. Sustainability 10(2), 503.

33. Zmyślony P., Kowalczyk-Anioł J. (2019). Urban tourism hypertrophy: who should deal with it? The case of Krakow (Poland). International Journal of Tourism Cities 5(2), 247269. DOI: 10.1108/IJTC-07-2018-0051.

34. Zmyślony P., Kowalczyk-Anioł J., Dembińska M. (2020). Deconstructing the overtourism-related social conflicts. Sustainability 12(4), 1695. DOI: 10.3390/sul2041695.

35. Del Chiappa G., Baggio R. (2015). Knowledge transfer in smart tourism destinations: Analysing the effects of a ne- 
twork structure. Journal of Destination Marketing $\mathcal{E}$ Management 4(3), 145-150.

36. Woo E., Uysal M., Sirgy M.J. (2018). Tourism impact and stakeholders' quality of life. Journal of Hospitality and Tourism Research 42(2), 260-286. DOI: 10.1177/1096348016654971.

37. Quaranta G., Citro E., Salvia R. (2016). Economic and social sustainable synergies to promote innovations in rural tourism and local development. Sustainability 8(7), 668. DOI: $10.3390 /$ su8070668.

38. Bimonte S., Faralla V. (2016). Does residents' perceived life satisfaction vary with tourist season? A two-step survey in a Mediterranean destination. Tourism Management 55, 199-208. DOI: 10.1016/j.tourman.2016.02.011.

39. Gu X., Hunt C.A., Lengieza M.L., Niu L., Wu H. et al. (2021). Evaluating residents' perceptions of nature-based tourism with a factor-cluster approach. Sustainability 13(1), 199. DOI: 10.3390/sul3010199.

40. Uysal M., Sirgy M.J. (2019). Quality-of-life indicators as performance measures. Annals of Tourism Research 76, 291300. DOI: 10.1016/j.annals.2018.12.016.

41. Cottrell S.P., Vaske J.J., Shen F. (2007). Modelling resident perceptions of sustainable tourism development: Applications in Holland and China. China Tourism Research 3(2), 205-234.

42. Hadinejad A., Moyle B.D., Scott N., Kralj A., Nunkoo R. (2019). Residents' attitudes to tourism: a review. Tourism Review 74(2), 150-165. DOI: 10.1108/TR-01-2018-0003.

43. Meimand S.E., Khalifah Z., Zavadskas E.K., Mardani A., Najafipour A.A., Ahmad U.N.U. (2017). Residents' attitude toward tourism development: A socio-cultural perspective. Sustainability 9(7), 1170. DOI: 10.3390/su9071170.

44. Liang Z.X., Hui T.K. (2016). Residents' quality of life and attitudes toward tourism development in China. Tourism Management 57, 56-67. DOI: 10.1016/j.tourman.2016.05.001.

45. Gupta M.R., Dutta P.B. (2018). Tourism development, environmental pollution and economic growth: A theoretical analysis. The Journal of International Trade and Economic Development 27(2), 125-144. DOI: 10.1080/09638199. 2017.1346139.

46. Hair J.F., Risher J.J., Sarstedt M., Ringle C.M. (2019). When to use and how to report the results of PLS-SEM. European Business Review 31(1), 2-24. DOI: 10.1108/EBR-11-20180203.

47. Hanafiah M.H. (2020). Formative vs. reflective measurement model: Guidelines for structural equation modeling research. International Journal of Analysis and Applications 18(5), 876-889. DOI: 10.28924/2291-8639-18-2020-876.

48. Henseler J., Ringle C.M., Sarstedt M. (2015). A new criterion for assessing discriminant validity in variance-based structural equation modeling. Journal of the Academy of Marketing Science 43(1), 115-135. DOI: 10.1007/s11747-014-0403-8.

49. Zaki S.A., Azid N.S., Shahidan M.F., Hassan M.Z., Md Daud M.Y. et al. (2020). Analysis of urban morphological effect on the microclimate of the urban residential area of Kampung Baru in Kuala Lumpur using a geospatial approach. Sustainability 12(18), 7301.

50. Hao Y.H., Bai H., Sun S. (2021). How does Covid-19 affect tourism in terms of people's willingness to travel? Empirical evidence from China. Tourism Review 76(4), 892-909, DOI: 10.1108/TR-09-2020-0424.

Submitted: June 29, 2021

Accepted: August 21, 2021 